\title{
Epigenetic modifications in the GH-dependent PrIr, Hnf6, Cyp7b1, Adh1 and Cyp2a4 genes
}

\author{
Belen Brie, Ana Ornstein, Maria Cecilia Ramirez, Isabel Lacau-Mengido and Damasia Becu-Villalobos \\ Instituto de Biología y Medicina Experimental, Consejo Nacional de Investigaciones Científicas y Técnicas, Buenos Aires, Argentina \\ Correspondence should be addressed to D Becu-Villalobos: dbecu@dna.uba.ar
}

\begin{abstract}
Many sex differences in liver gene expression originate in the brain, depend on GH secretion and may underlie sex disparities in hepatic disease. Because epigenetic mechanisms may contribute, we studied promoter methylation and microRNA abundance in the liver, associated with expression of sexual dimorphic genes in mice with selective disruption of the dopamine D2 receptor in neurons (neuroDrd2KO), which decreases hypothalamic Ghrh, pituitary GH, and serum IGFI and in neonatally androgenized female mice which have increased pituitary GH content and serum IGFI. We evaluated mRNA levels of the female predominant genes prolactin receptor (Prlr), alcohol dehydrogenase 1 (Adh1), Cyp2a4, and hepatocyte nuclear transcription factor 6 (Hnf6) and the male predominant gene, Cyp7b1. Female predominant genes had higher mRNA levels compared to males, but lower methylation was only detected in the Prlr and Cyp2a4 female promoters. In neuroDrd2KO mice, sexual dimorphism was lost for all genes; the upregulation (feminization) of Prlr and Cyp2a4 in males correlated with decreased methylation of their promoters, and the downregulation (masculinization) of Hnf-6 mRNA in females correlated inversely with its promoter methylation. Neonatal androgenization of females evoked a loss of sexual dimorphism only for the female predominant Hnf6 and Adh1 genes, but no differences in promoter methylation were found. Finally, mmumiR-155-5p, predicted to target Cyp7b1 expression, was lower in males in association with higher Cyp7b1 mRNA levels compared to females and was not modified in neuroDrd2KO or TP mice. Our results suggest specific regulation of gene sexually dimorphic expression in the liver by methylation or miRNAs.
\end{abstract}

\author{
Key Words \\ - PRLR \\ - liver \\ - $\mathrm{GH}$ \\ methylation \\ - miRNa
}

\section{Introduction}

Many sex differences in liver gene expression originate in the brain, depend on GH secretory patterns, and are imprinted by neonatal gonadal steroids (Jansson \& Frohman 1987). There is an emerging interest in the epigenetic mechanisms contributing to the maintenance of permanent changes established during hormonally induced sexual differentiation of the brain
(Nugent \& McCarthy 2011, Lenz et al. 2012), which program sexual dimorphism and metabolic function of the liver. DNA methylation, histone modification patterns, or miRNAscan be potential mechanisms by which lifelong changes in gene expression are maintained.

Sexual dimorphism of liver genes may underlie sex differences in hepatic disease, and furthermore, 
loss of dimorphism may condition disease occurrence in humans or rodents. For example, sex-specific GH patterns, by modifying gene expression in the liver, may shape the sensitivity to thrombosis, dislipidemia, coronary artery disease, liver lesions or hepatocellular carcinoma (HCC) development (Liao et al. 1993, Wong et al. 2008, Zhang et al. 2011). Furthermore, differential susceptibility to some liver diseases between sexes has been described. For example, chronic hepatitis, primary sclerosing cholangitis, HCC, nonalcoholic fatty liver disease (NAFLD), steatohepatitis or liver fibrosis progression predominate in males, while primary biliary cirrhosis, autoimmune hepatitis or alcoholic liver disease do so in females (Poynard et al. 1997, Rogers et al. 2007, Guy \& Peters 2013, Durazzo et al. 2014, Buzzetti et al. 2017). The pituitary gland, mostly dictating GH secretory patterns is involved in this sexual dimorphism, while prolactin secretion, which regulates liver Prlr expression in females, may also participate.

We have previously shown that sexually differentiated expression of some GH-dependent liver genes may be permanently modified by neonatal androgen exposure in female mice (Ramirez et al. 2010), and by neonatal xenoestrogens in female rats (Ramirez et al. 2012). Furthermore, we showed that impaired GHRH-GH-IGF1 axis disrupts sexual dimorphism of many genes in mice (Ramirez et al. 2015), and that high levels of prolactin modify liver Prlr mRNA levels (Ramirez et al. 2015). We now explore a possible relationship between the alterations in liver gene dimorphic expression in these models and epigenetic regulation, such as the methylation status of gene promoter regions, or abundance of specific miRNAs which regulate transcripts.

DNA methylation of CpGs decreases gene expression by preventing the binding of the transcriptional machinery on a gene's promoter, or by recruiting methylbinding and chromatin remodeling proteins which cause chromatin to condense (Garcia-Carpizo et al. 2011). In general, methylation of a promoter is inversely associated with gene expression. This modification can be duplicated across cellular division and maintained throughout a lifespan.

MiRNAs are short non-coding RNAs that play an important role in post-transcriptional regulation of gene expression. miRNAs repress translation, partly by targeting mRNAs for degradation based on partial complementary pairing of the miRNA seed region to the seed match site region of the target mRNA. MiRNAs have the capacity of targeting multiple genes, thus regulating the expression of several proteins. Some liver miRNAs are sexually dimorphic (Hao \& Waxman 2018), but not many have been validated in determining sex differences in liver gene expression.

We studied promoter methylation and miRNA abundance in the liver in association with sexual dimorphic expression of female predominant genes. We chose genes from a group of more than a thousand GH-dependent genes that are differentially expressed in the liver in females and males (Clodfelter et al. 2007), and which are important in liver function and disease: the prolactin receptor (Prlr), alcohol dehydrogenase 1 (Adh1), the steroid $15 \alpha$-Hydroxylase (Cyp2a4), and hepatocyte nuclear transcription factor 6 (Hnf6), and included a male predominant gene $C y p 7 b 1$. Regulation of these genes by GH has been demonstrated by us and others (Waxman \& Holloway 2009, Wauthier et al. 2010, Ramirez et al. 2015).

The prolactin receptor has multiple homeostatic roles (Goffin et al. 2002), and, in particular, it may protect the liver from NAFLD (Shao et al. 2018, Zhang et al. 2018), prevent HCC and inflammation (Hartwell et al. 2014), and modify hepatic drug metabolism (Tracy et al. 2005). HNF6 is a transcription factor involved in glucose metabolism, bile homeostasis, inflammation, and a possible target in liver fibrosis, tumorigenesis, and cholestasis (Wang \& Holterman 2012). CYP2A4 is a steroid $15 \alpha$-hydroxylase that catalyzes one of the hydroxylation reactions leading to further metabolism of the sex hormones, testosterone and estradiol, in the liver. Alcohol dehydrogenase 1 metabolizes the majority of ethanol through oxidation (Simon et al. 2002) and is relevant when considering the predisposition of toxic effects exerted by alcohol. And finally, CYP7B1 is cytochrome P450 enzyme that hydroxylates oxysterols and steroids and is paramount in hepatic bile salt synthesis, and in the inactivation of otherwise hepatotoxic oxysterols.

We studied female and male mice with selective disruption of the dopamine D2 receptor in neurons (neuroDrd2KO), in which hypothalamic expression of Ghrh is decreased, pituitary content of GH and serum IGFI are lower, and GH pulsatility is greatly impaired (Noain et al. 2013, Ramirez et al. 2015); and neonatally androgenized female mice (TP) which have increased GH pituitary content, increased serum IGFI compared to control females, but full male GH pulsatility is not achieved (Ramirez et al. 2010). We aimed at establishing the specificity of epigenetic modulation by promoter methylation or miRNA abundance on the regulation of sexual dimorphism, and their relation to the GH axis in each model. 


\section{Materials and methods}

\section{Animals}

\section{Neonatally androgenized females}

C57BL/6J mice were housed in temperature-controlled room with lights on at 07:00 $\mathrm{h}$ and lights-off at 19:00 h, and free access to laboratory chow and tap water. On the day of birth (day 0) the pups were left undisturbed, and on the second day they were sexed and each pup was randomly divided into treatment groups: males, females, and females injected subcutaneously with $100 \mathrm{~g}$ testosterone propionate (Sigma) in $0.010 \mathrm{~mL}$ castor oil (neonatally androgenized females: TP females). The dose chosen has been described to effectively androgenize neonatal brain in mice (Livne et al. 1992, Ramirez et al. 2010). Females and males from the same cohort were injected with castor oil and used as controls. Animals were weighed and killed at 4 months of age. As previously described TP females had an intermediate body weight, percentage of somatotropes and pituitary GH content compared to females, and males (Ramirez et al. 2010). Serum IGF I levels were similar in males and TP females, and higher than females. On the other hand, liver Mup1/2/6/8 mRNA levels, a marker of male $\mathrm{GH}$ pulsatility, were similar in females and TP females, and lower than in males. This indicates that even though pituitary GH content was increased in TP females, complete masculinization of male pulsatility was not achieved, suggesting that not only GH levels but also pulsatility is important for full expression of many male genes. Control females in diestrus and TP females in diestrus/anestrus were used, as TP females had highly irregular cycles.

\section{Mice lacking D2Rs in neurons (neuroDrd2KO)}

To ablate D2Rs from cells of neural origin, $\operatorname{Drd2} 2^{\text {loxP/loxP }}$ mice (Bello et al. 2011) were crossed with B6.Cg-Tg(Nes-cre)1 ${ }^{1 \mathrm{Kln} / \mathrm{J}}$ to obtain cohorts of Drd2 loxP/loxP (control mice) and Drd2loxP/ loxP.B6.Cg-Tg(Nes-cre)1Kln/J littermates (Noain et al. 2013). Thereafter, breeding pairs of Drd2 loxp/loxPand Drd2loxP/loxP. $\mathrm{Tg}(\mathrm{Nes}-\mathrm{Cre})^{1 \mathrm{Kln} / \mathrm{J}}$ mice were used to generate $\mathrm{Drd} 2^{\text {loxP/loxP }}$ (control) and Drd2 loxP/loxP.Tg(Nes-Cre) (neuroDrd2KO) littermates (Noain et al. 2013). Body weight was lower in male and female neuroDrd2KO mice compared to their control littermates $\operatorname{Drd} 2^{\text {loxp } / \text { loxp }}$ mice (Table 1). Furthermore, the GH axis was decreased in neuroDrd2KO of both sexes: they had lower pituitary GH content, liver Igf1 mRNA levels, serum IGF1 and urine MUPs compared to Drd2 $2^{\text {loxP/loxP }}$ sex-matched mice. NeuroDrd2KO males also had decreased Mup mRNA levels compared to Drd2loxP/loxP males. Pituitary GH content, liver Igf1 and Mup1 mRNA levels, and urine MUPS were higher in males compared to females. Prolactin levels were higher in females, and $\mathrm{LH}$ and FSH were not altered by genotype. Liver Igfbp3 was similar in all groups (Table 1) (Noain et al. 2013, Ramirez et al. 2015).

All experimental procedures were performed in 4to 6-month-old mice. The institutional animal care and use committee of the Instituto de Biología y Medicina Experimental, Buenos Aires granted approval, protocol

Table $1 \mathrm{GH}$ axis in neuroDrd2KO mice.

\begin{tabular}{|c|c|c|c|c|c|}
\hline & \multicolumn{2}{|c|}{ Female } & \multicolumn{2}{|c|}{ Male } & \multirow[b]{2}{*}{ Statistics } \\
\hline & Drd2 $2^{\text {loxP/loxP }}$ & NeuroDrd2KO & $D r d 2^{\text {IoxP/loxP }}$ & NeuroDrd2KO & \\
\hline $\mathrm{BW}(\mathrm{g})$ & $27.0+0.7$ & $22.0+0.5$ & $33.0+0.8$ & $26.0+0.5$ & Genotype, sex \\
\hline$n$ & 12 & 8 & 9 & 7 & \\
\hline Pituitary GH (ng/ug prot) & $263+87$ & $108+38$ & $398+84$ & $136+0.6$ & Genotype, sex \\
\hline$n$ & 7 & 6 & 13 & 16 & \\
\hline Liver Igf1I & $116+11$ & $45+4$ & $100+11$ & $37+7$ & Genotype \\
\hline$n$ & 8 & 9 & 10 & 6 & \\
\hline Liver Igfbp3 & $147+29$ & $165+25$ & $100+12$ & $134+28$ & NS \\
\hline$n$ & 8 & 9 & 10 & 6 & \\
\hline Liver Mup1 & $18+4$ & $12+5$ & $100+18$ & $30+4$ & Sex, genotype only males \\
\hline$n$ & 8 & 9 & 7 & 8 & \\
\hline Serum IGF1 (ng/mL) & $792+83$ & $393+58$ & $648+45$ & $463+24$ & Genotype \\
\hline$n$ & 8 & 9 & 10 & 8 & \\
\hline Urine MUP (AU) & $48.2+8.9$ & $15.4+3.5$ & $100.0+5.8$ & $54.2+3.5$ & Genotype, sex \\
\hline$n$ & 12 & 5 & 18 & 8 & \\
\hline Prolactin (ng/mL) & $235+60$ & $267+57$ & $182+32$ & $182+51$ & Sex \\
\hline$n$ & 8 & 9 & 10 & 8 & \\
\hline
\end{tabular}

Data are presented as means + S.E.M. Genotype: indicates significant differences between genotypes $(P \leq 0.05)$ in both sexes. Sex: indicates significant differences between males and females $(P \leq 0.05)$ in both genotypes.NS, non significant.

https://jme.bioscientifica.com

https://doi.org/10.1530/JME-19-0205
(C) 2020 Society for Endocrinology Published by Bioscientifica Ltd. Printed in Great Britain 
\#07/2016 (in accordance with the Division of Animal Welfare, Office for Protection from Research Risks, NIH, Animal Welfare Assurance for the Institute of Biology and Experimental Medicine A\#5072-01).

\section{Tissue RNA extraction and total cDNA preparation for Hnf-6, Adh1, PrIr, Cyp2a4, and Cyp7b1 expression by real-time PCR}

After euthanasia, liver samples (50 mg) were immediately homogenized in TRI Reagent (Molecular Research Center, Inc) and stored at $-70^{\circ} \mathrm{C}$ until total RNA was isolated as previously described (Ramirez et al. 2015). First-strand cDNA was synthesized from $1 \mu \mathrm{g}$ of total RNA as previously described (Ramirez et al. 2015).

\section{Quantitative real-time PCR}

Sense and antisense oligonucleotide primers were designed based on previously published results or by the use of PrimerBlast (http://www.ncbi.nlm.nih.gov/tools/primerblast/). Oligonucleotides were obtained from Invitrogen. The sequences are described in Table 2.

Quantitative measurements of specific mRNA levels were performed by kinetic PCR using HOT FIREPol EvaGreen qPCR Mix Plus (ROX) Solis BioDyne as previously described (Ramirez et al. 2015). After denaturation at $95^{\circ} \mathrm{C}$ for $15 \mathrm{~min}$, the cDNA products were amplified for 40 cycles, each cycle consisting of denaturation at $95^{\circ} \mathrm{C}$ for $20 \mathrm{~s}$, annealing and extension at $60^{\circ} \mathrm{C}$ for $1 \mathrm{~min}$, and optical reading stage at $80^{\circ} \mathrm{C}$ for $33 \mathrm{~s}$. The accumulating DNA products were monitored by the Biorad CFX96 Touch $^{\mathrm{TM}}$ (Biorad), and data were stored continuously during the reaction. The results were validated based on the quality of dissociation curves generated at the end of the PCR runs by ramping the temperature of the samples from 60 to $95^{\circ} \mathrm{C}$, while continuously collecting fluorescence data. Product purity was confirmed by agarose gel electrophoresis. Each sample was analysed in duplicate. Relative gene expression levels were calculated according to the comparative cycle threshold (CT) method. Cyclophilin was used as housekeeping gene, and CTs did not show sex differences and were not altered in the different experimental groups.

\section{Stemloop RT-qPCR for microRNA expression}

A specific Stemloop primer was designed for each microRNA to be analyzed (sequences in Table 2), and used for the RT reaction (instead oligoDT, from the conventional protocol for mRNA), at a final concentration of $1 \mu \mathrm{M}$. It was incubated with $500 \mu \mathrm{g}$ of RNA for two min at $65^{\circ} \mathrm{C}$ and then left on ice for $1 \mathrm{~min}$. A master mix with 10× Buffer (1×), DNTPS (0.4 mM), DTT (0.004 mM) and MML-V (200u; Epicentre, Madison, WI) was added to each tube. They were incubated at $16^{\circ} \mathrm{C}$ for $30 \mathrm{~min}, 37^{\circ} \mathrm{C}$ for $60 \mathrm{~min}$ and $85^{\circ} \mathrm{C}$ for $5 \mathrm{~min}$. The cDNA obtained was relatively quantified through qPCR.

\section{DNA extraction for methylation studies}

The tissue was placed in liquid nitrogen and crushed with mortar (and on dry ice). The powder was suspended in digestion buffer with proteinase $\mathrm{K}$ (stock $20 \mathrm{mg} / \mathrm{mL}$, $35 \mu \mathrm{L}$ in $1.2 \mathrm{~mL}$ ). Samples were then incubated at $50^{\circ} \mathrm{C}$ for 12-18 hours. They were centrifuged for $15 \mathrm{~min}$ at 12,000 rpm and the supernatant was preserved. One volume of phenol-chloroform-isoamyl (25:24:1, Sigma-Aldrich) was added, then mixed by inversion and left for $2 \mathrm{~min}$ at room temperature. The samples were centrifuged for $10 \mathrm{~min}$ at $12,000 \boldsymbol{g}$, the aqueous phase transferred to a new tube and $1 / 2$ volume of $7.5 \mathrm{M}$ Ammonium Acetate and 1 volume of isopropanol were added. After incubating at $-20^{\circ} \mathrm{C}$ for $30 \mathrm{~min}$, they were centrifuged for $15 \mathrm{~min}$ at $12,000 \mathrm{rpm}$ and the supernatant removed. The pellet was washed with $1 \mathrm{~mL}$ of $70 \% \mathrm{ETOH}$ and left to dry at room temperature. Finally, it was resuspended in $80 \mu \mathrm{L}$ of molecular $\mathrm{H}_{2} \mathrm{O}$.

\section{Treatment with methylation sensitive restriction enzymes}

The Mix was prepared at room temperature at a final volume of $50 \mu \mathrm{L}\left(1 \times\right.$ FastDigest ${ }^{\circledR}$ Buffer, $5 \mu \mathrm{g}$ of genomic DNA (in $10 \mu \mathrm{L}$ of water), 5 units of FastDigest ${ }^{\circledR}$ Enzyme (treated DNA) or water for untreated samples, that served as internal controls. It was mixed gently, spinned down and incubated at $37^{\circ} \mathrm{C}$ for $5 \mathrm{~min}$ and then at $65^{\circ} \mathrm{C}$ for $5 \mathrm{~min}$ to inactivate the enzyme. A qPCR was then performed, using primers listed on Table 2, to the enzyme treated and untreated DNA. Amplification of treated DNA was relativized to that of untreated DNA of the same sample. We used the FastDigest ${ }^{\circledR}$ (Thermo Scientific) enzymes HpaII and HhaI for this test.

\section{In silico search for CpG islands in the promoters of PrIr, Hnf6, Cyp2a4, Adh1 and Cyp7b1}

The search for CpG islands was performed using the Methyl Primer Express 1.0 software (Applied Biosystems). For each gene, the promoter region sequences were 


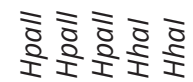

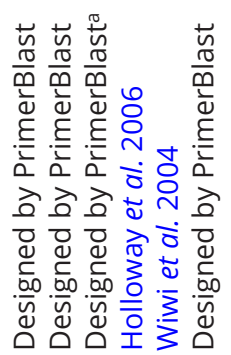

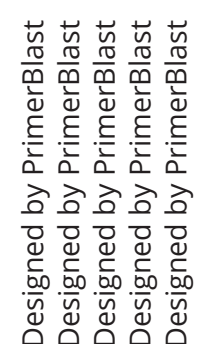

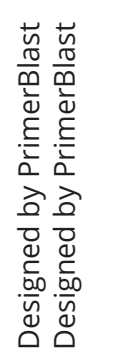

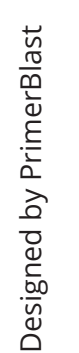
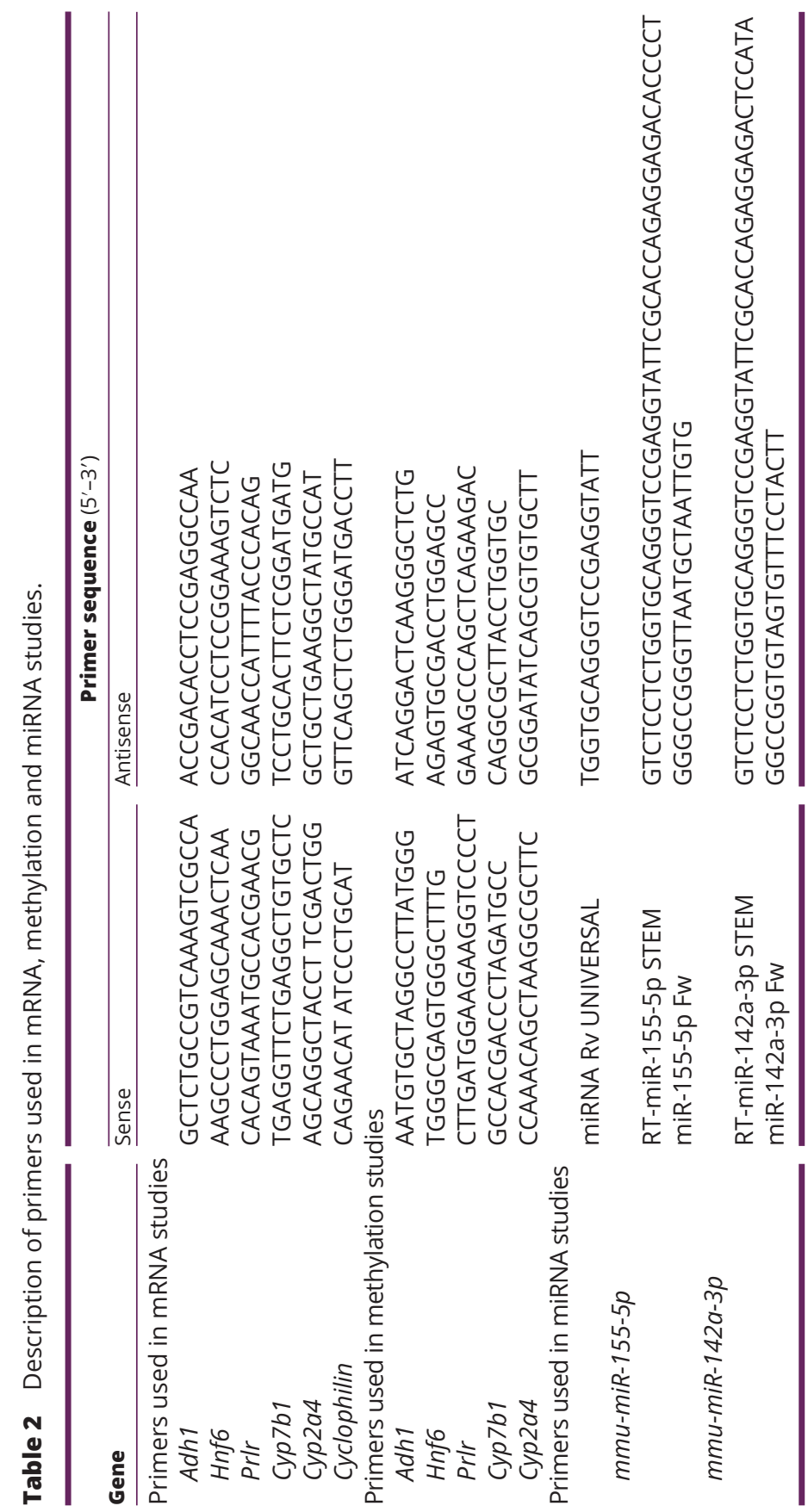
obtained from the Ensembl program http://www.ensembl. org/Mus_musculus/Info/Index.

\section{In silico prediction of binding sites for transcription factors in the proximal promoters of PrIr, Hnf6 and Cyp2a4}

For the identification of putative transcription factor binding sites in the proximal promoter regions of Prlr, Hnf6 and Cyp2a4, we first used the program PROMO from the Algorithmics and Genetics Group (ALGGEN) (Messeguer et al. 2002). The resulting list of putative binding sites extracted using this bioinformatic tool was then narrowed down by the analysis of published data which validated, using Chip-seq, those transcription factors that bound to sequences proximal to the promoter region of the genes of interest (Mueller et al. 1990, Miura \& Tanaka 1993, Lahuna et al. 2000, Yoshida et al. 2006, Negri-Cesi et al. 2008, Bolotin et al. 2011, Zhang et al. 2012).

\section{Statistical analysis}

Results are expressed as means \pm s.E.M. The differences between means were analysed by Student's $t$ test (two groups); and ANOVA followed by Newman-Keuls test or Tukey's HSD test for unequal $\mathrm{N}$ for females, TP females and males. For the analysis of gene and miRNA expression, and promoter methylation in neuroDrd2KO mice twoway ANOVA for the effects of sex and genotype for independent measures was used. If $P$ of the interaction was significant, individual means were compared by Tukey's honest significant difference test; if it was not significant, groups of means were analysed by the same test. KruskallWallis test was performed when a non-parametric test was necessary. We evaluated correlation by Spearman's rank correlation coefficient, $P<0.05$ was considered significant.

\section{Results}

Sexual dimorphism of liver Hnf6 mRNA and promoter methylation levels in neuroDrd2KO mice and neonatally androgenized females

Expression levels of Hnf6 was 2.80-fold higher in females compared to males confirming female predominance of this gene ( $P \leq 0.05$; Fig. $1 \mathrm{~A})$, while methylation levels of the Hnf6 promoter were similar in both sexes (Fig. 1B).

In female neuroDrd2KO mice there was a significant downregulation of Hnf6 mRNA expression levels compared to female $\operatorname{Drd} 2^{\text {loxPloxp }}$ mice, and sexual dimorphism for this gene was lost (Fig. 1C). Furthermore, there was an increase in the methylation status of the Hnf6 promoter in neuroDrd2KO females compared to controls (Fig. 1D), yielding a significant inverse correlation of mRNA levels and promoter methylation for this gene in females (Fig. 1D inset, $P$ correlation $=0.016$ ). On the other hand, expression and methylation levels of the Hnf6 gene in males were not modified in neuroDrd2KO compared to $\operatorname{Drd}^{\text {loxPlloxp }}$ mice (Fig. 1B and C).

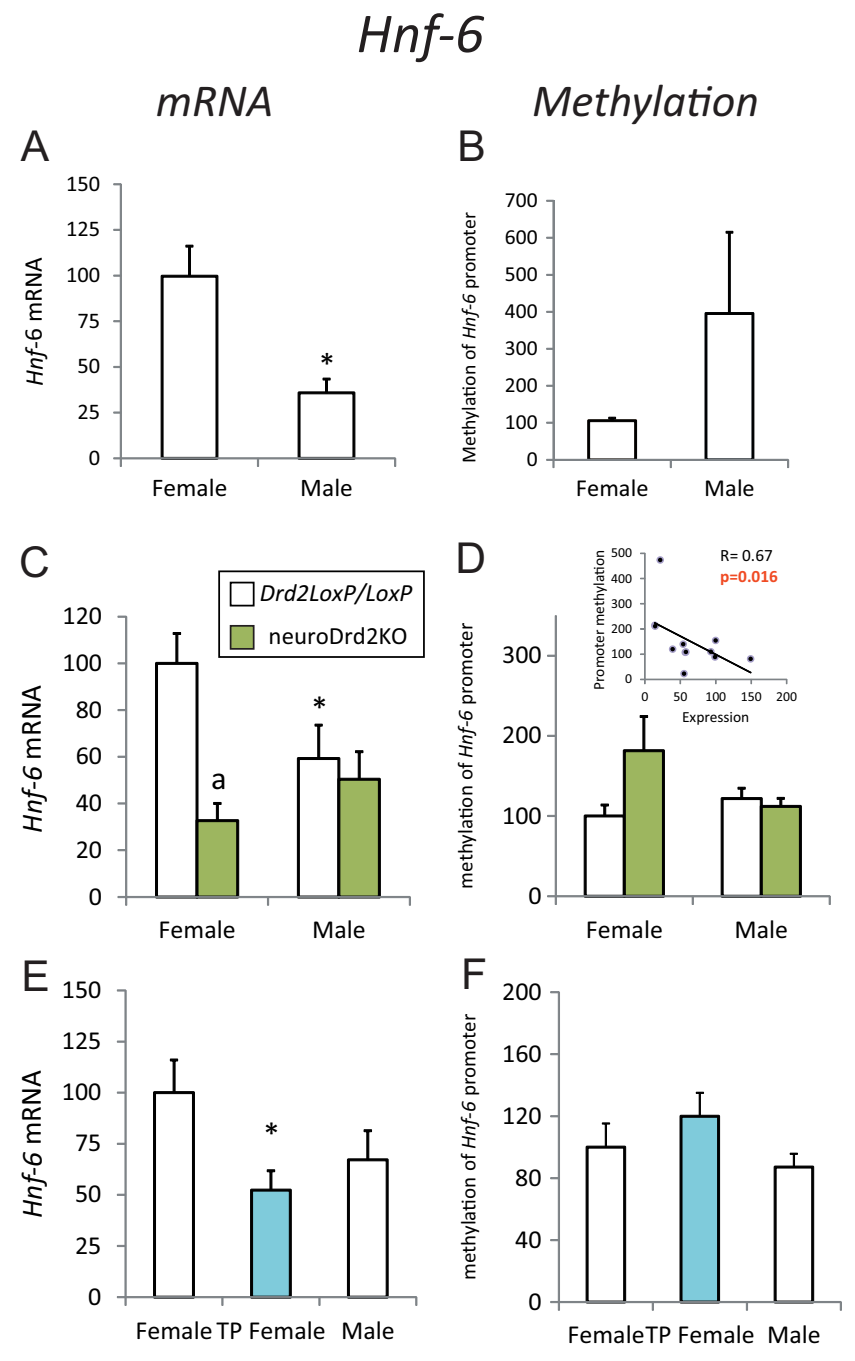

\section{Figure 1}

Hnf6 mRNA levels and methylation of its promoter in (A and B) female and male mice; ( $C$ and $D$ ) female and male neuroDrd2KO and Drd2/oxP/loxP mice, and ( $E$ and F) females, neonatally androgenized females (TP female) and males. Inset (D) correlation of Hnf6 expression and methylation of its promoter in female Drd2loxP/loxP and neuroDrd2KO mice. $n$ (for this and following figures the number of samples is defined from left to right within each panel) $=19,23(A), 14-21(B) ; 11,10,9,11$ (C); 6,6,5,6 (D); 13,16,13 (E); $6,6,9$ (F). * $P \leq 0.05$ vs females (genotype matched); 'a' $P \leq 0.05$ vs Drd2/ 1 xP/loxP sex-matched mice. A full colour version of this figure is available at https://doi.org/10.1530/JME-19-0205. 
Neonatal androgenization of females decreased the expression levels of this gene compared to control females (Fig. 1D), but methylation of the Hnf6 promoter was similar in the three groups (Fig. 1E).

\section{Sexual dimorphism of liver PrIr mRNA and promoter methylation levels in neuroDrd2KO mice and neonatally androgenized females}

Expression levels of Prlr confirmed female predominance for this gene in mice (Fig. 2A; $P \leq 0.0001$; female/male ratio=3.86). Methylation of the Prlr promoter was significantly higher in males ( $P=0.041$, Fig. 2B), and a significant inverse correlation for Prlr gene expression and methylation status of the promoter was verified for Prlr in livers from male and female mice ( $P=0.018$; Fig. $2 \mathrm{C}$ ).

In neuroDrd2KO mice sexual dimorphism of the Prlr gene was lost (Fig. 2D), indicating that the action of the central D2R is paramount in dictating sexual dimorphism of GH-dependent genes, and that the liver Prlr is not only a prolactin-inducible gene but also under GH control. Furthermore, in neuroDrd2KO males, Prlr expression was significantly upregulated (feminized) $(P=0.006)$, and the methylation of the Prlr promoter decreased compared to neuroDrd2 $2^{\text {Loxp } / \text { loxP }}$ male mice, yielding a significant inverse correlation between mRNA levels and methylation of the promoter $(P$ correlation $=0.041$, Fig. $2 \mathrm{~F})$.

Neonatal androgenization of females (TP females) did not alter the sexual dimorphism of this female predominant gene (Fig. 2G), or the methylation status of the Prlr promoter, which was higher in livers from male mice compared to females and TP females (Fig. 2H). There was also a significant inverse correlation of mRNA levels and methylation of the promoter for the Prlr in this model (Fig. 2I, $P$ correlation $=0.018$ ).

\section{Sexual dimorphism of liver Adh1 mRNA and promoter methylation levels in neuroDrd2KO mice and neonatally androgenized females}

Expression levels of $A d h 1$ confirmed female predominance for this gene (Fig. 3A; $P \leq 0.016$; female/male ratio=1.41). Methylation of the Adh1 promoter was similar between sexes (Fig. 3B).

Adh1 mRNA levels were not modified in neuroDrd2KO mice compared to $\operatorname{Drd} 2^{\text {loxp } / o x P}$ mice, though sexual dimorphism was also lost for this gene (Fig. 3C). On the other hand, neonatal androgenization decreased its expression, and sexual dimorphism was also lost (Fig. 3E).

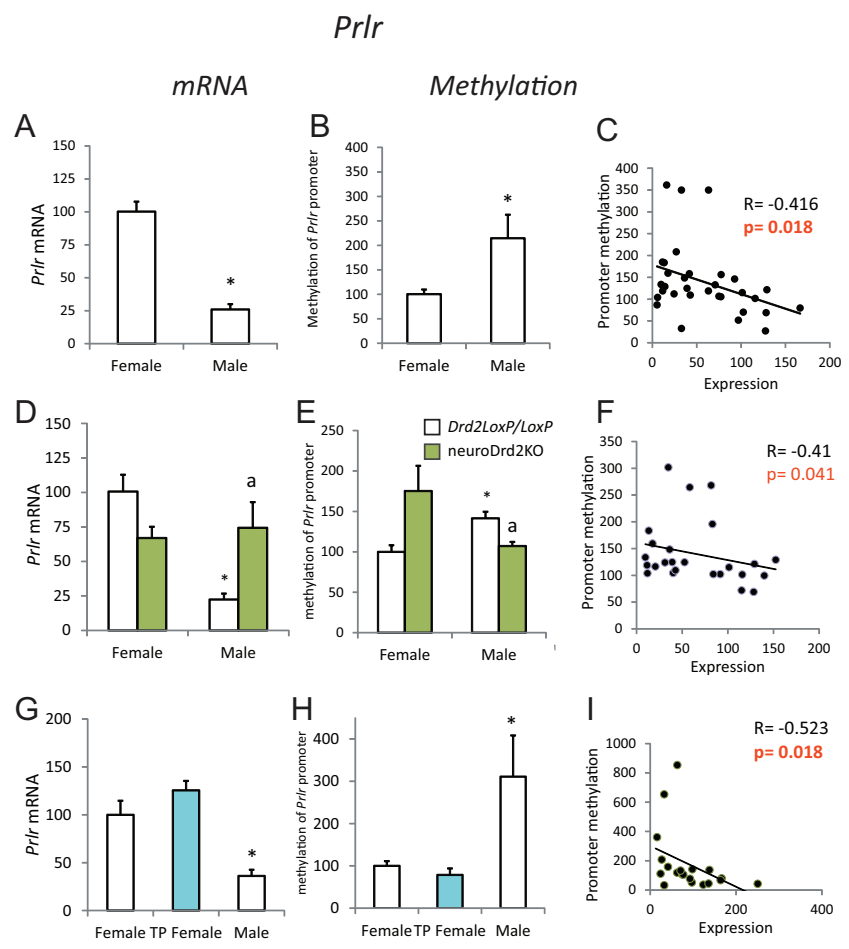

\section{Figure 2}

PrIr mRNA levels, methylation of its promoter and correlation of expression and methylation in (A, B and C) female and male mice; (D, E and $\mathrm{F}$ ) female and male neuroDrd2KO and Drd2/oxP/loxP mice (F: correlation of data from male neuroDrd2KO and Drd2/oxP/loxP mice), and (G, H and I) females, neonatally androgenized females (TP female) and males. $n=16$, 20 (A), 14,18 (B); 6,6,7,8 (C); 6,8,8,9 (D); 5,6,9 (E); 6,7,8 (F). * $P \leq 0.05$ vs females (genotype matched); ' $a$ ' $P \leq 0.05$ vs Drd2/oxP/loxP sex-matched mice, ' $b$ ' $P \leq 0.05$ vs TP females. A full colour version of this figure is available at https://doi.org/10.1530/JME-19-0205.

Methylation pattern of the promoter did not correlate with any of the changes observed (Fig. 3D and F).

\section{Sexual dimorphism of liver Cyp2a4 mRNA and promoter methylation levels in neuroDrd2KO mice and neonatally androgenized females}

Liver expression levels of Cyp2a4 confirmed female predominance for this gene (Fig. 4A; $P=0.018$; female/ male ratio $=2.60$ ). Methylation of the Cyp2a4 promoter was higher in male mice ( $P=0.0014$; Fig. $4 \mathrm{~B})$.

In neuroDrd2KO males, Суp2a4 was significantly upregulated (feminized) ( $P=0.05$, Fig. 4C), similar to results found for the Prlr gene, and mRNA expression and methylation status of the promoter (Fig. 4D) correlated inversely in male mice (Fig. 4D inset, $P$ correlation $=0.041$ ).

On the other hand, neonatal androgenization did not modify Cyp2a4 expression or methylation status of the promoter (Fig. 4F and G). 


\section{Adh1}

$m R N A$

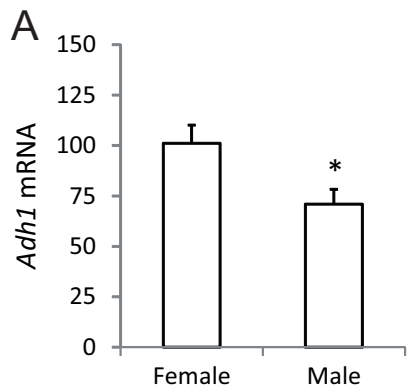

C

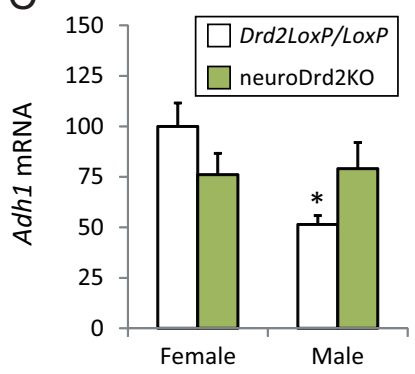

$\mathrm{E}$

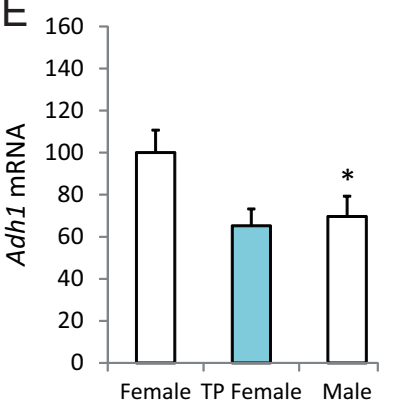

Methylation
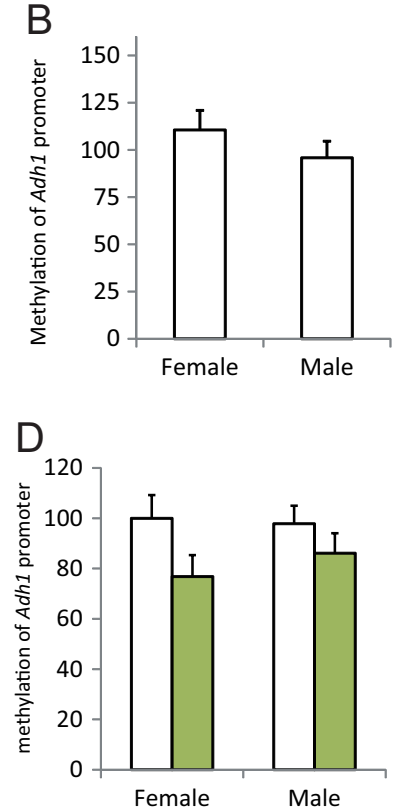

$\mathrm{F}$

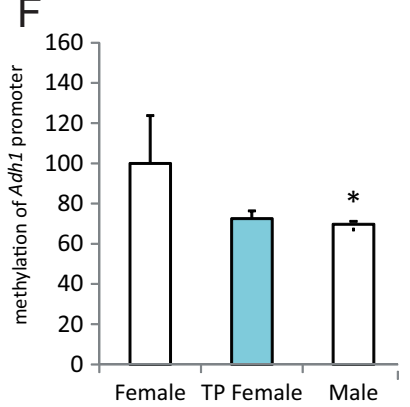

Figure 3

Adh1 mRNA levels and methylation of its promoter in ( $\mathrm{A}$ and $\mathrm{B}$ ) female and male mice; ( $C$ and $D$ ) female and male neuroDrd2KO and Drd2/oxP/loxP mice, and ( $E$ and $F$ ) females, neonatally androgenized females (TP female) and males. $n=16,21$ (A), 17-21 (B); 11,12,12,11 (C); 9,8,9,9 (D); 14,16,16 (E); $6,7,9(F) .{ }^{*} P \leq 0.05$ vs females (genotype matched). A full colour version of this figure is available at https://doi.org/10.1530/JME-19-0205.

\section{Sexual dimorphism of liver Cyp7b1 mRNA and} promoter methylation levels in neuroDrd2KO mice and neonatally androgenized females

Expression levels of $C y p 7 b 1$ confirmed male predominance for this gene (Fig. $5 \mathrm{~A} ; P=0.0002$; female $/$ male ratio $=0.18$ ), though methylation of the $C y p 7 b 1$ promoter was similar in both sexes (Fig. 5B).

In livers from male neuroDrd2KO mice the expression of $C y p 7 b 1$ was significantly decreased compared to livers from Drd2 $2^{\text {loxp } / \text { loxP }}$ mice (Fig. 5D; $P=0.0009$ ), with no
Cyp2a4

mRNA

Methylation
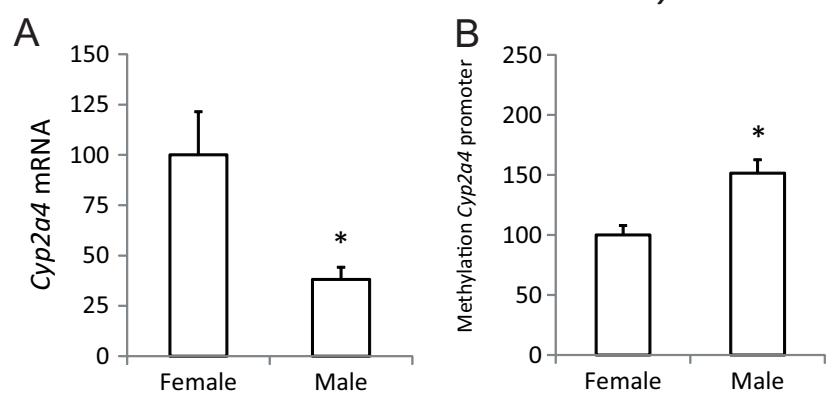

C
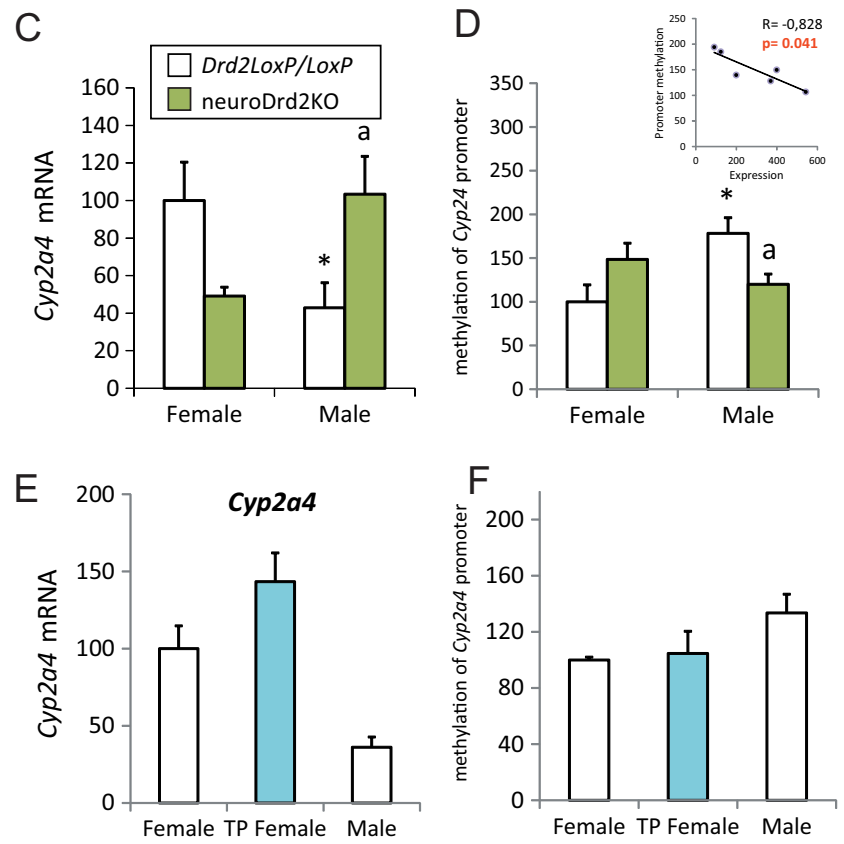

Figure 4

Cyp2a4 mRNA levels and methylation of its promoter in (A and B) female and male mice; (C and D) female and male neuroDrd2KO and Drd2/oxP/loxP mice (panel $C$ is reproduced from Ramirez et al. (2015) by permission of Oxford University Press); and (E and F) females, neonatally androgenized females (TP female) and males. Inset D) correlation of Adh1 expression and methylation of its promoter in female Drd2 loxP/loxP and neuroDrd2KO mice. $n=12,11$ (A), 15,19 (B); 7,9,9,8 (C); 5,6,6,5 (D); 13,16,13 (E); 6,6,9 (F). ${ }^{*} P \leq 0.05$ vs females (genotype matched); 'a' $P \leq 0.05$ vs Drd2loxP/loxP sex-matched mice. A full colour version of this figure is available at https://doi.org/10.1530/JME-19-0205.

modification in the methylation pattern of the promoter in either sex (Fig. 5E).

Neonatal androgenization of females did not modify the low expression of this male gene compared to untreated females (Fig. 5G), and no differences in the methylation pattern was observed for this gene (Fig. 5H). 
In silico prediction of transcription binding sites in the CpG islands of proximal promoters analysed for PrIr, Cyp2a4 and Hnf6

For this analysis we chose the three genes which showed an association of methylation of CpGs in gene expression. For the Hnf6 gene a large CpG island was found in the proximal promoter and exon 1. In silico prediction, using a bioinformatic tool together with the validation of Chip-seq analysis from the literature, showed that STAT5B, HNF4 and HNF6-binding sites were found in the CpG island studied. The analysed CpG sites sensitive to enzyme HpaII encompassed by tested primers were located proximal to binding sites for

\section{Cyp7b1}
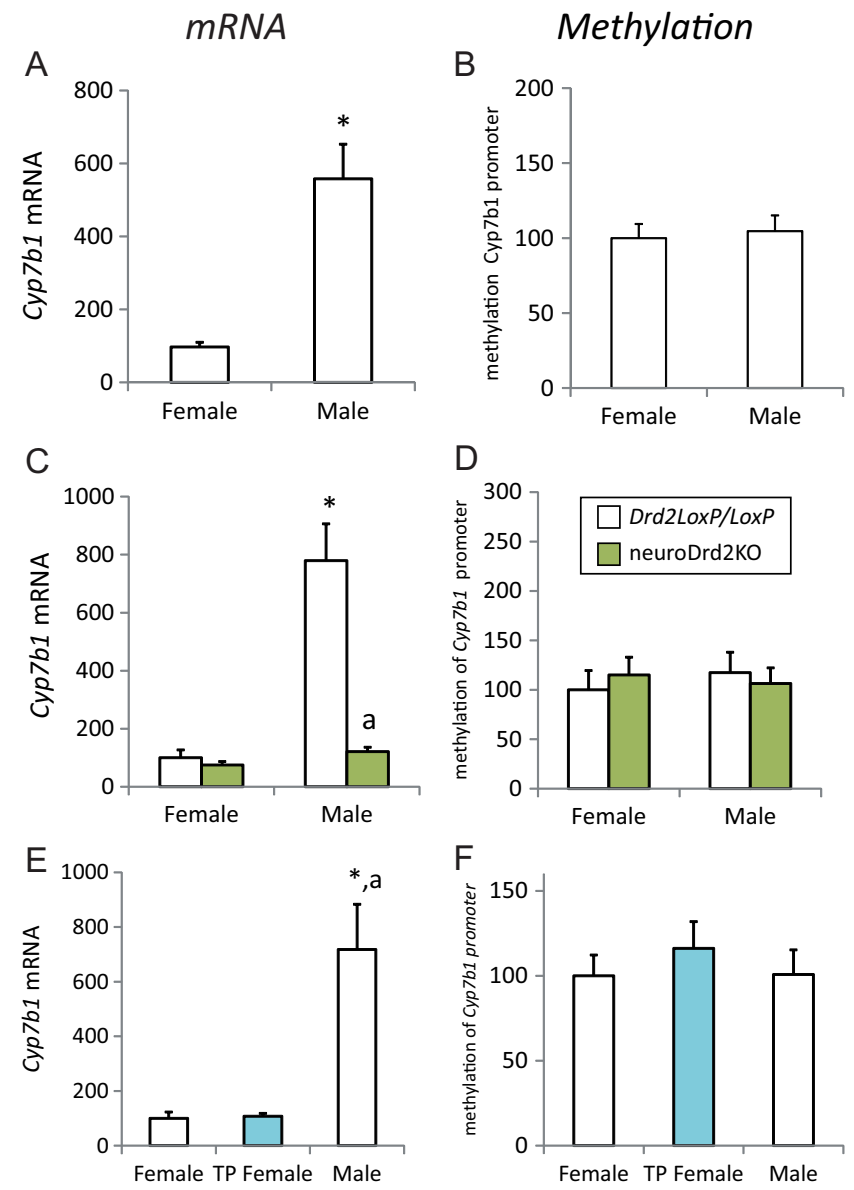

\section{Figure 5}

Cyp7b1 mRNA levels and methylation of its promoter in (A and B) female and male mice; ( $C$ and $D$ ) female and male neuroDrd2KO and Drd2loxP/loxP mice, and ( $E$ and $F$ ) females, neonatally androgenized females (TP female) and males. $n=16,20$ (A), 16,18 (B); 5,6,6,5 (C); 6,6,5,6 (D); 6,7,9 (E); 7,5,8 (F). $* P \leq 0.05$ vs females (genotype matched); ' $a$ ' $P \leq 0.05$ vs Drd2/oxP/loxP sex-matched mice, ' $b$ ' $P \leq 0.05$ vs TP females. A full colour version of this figure is available at https://doi.org/10.1530/JME-19-0205.
CCAAT/enhancer binding protein (C/EBP) C/EBP, SP1 and HNF4 transcription factors (Fig. 6A).

For the Prlrgene there was a $\mathrm{CpG}$ island located in exon 1. In silico prediction, together with validated published data, showed that the analysed CpG sites in the Prlr gene sensitive to the enzyme HpaII were located proximally to C/EBP-binding sites and that HNF4 and STAT5B-binding sites were found in this $\mathrm{CpG}$ island (Fig. 6B).

For the Cyp2a4 gene a CpG island was found within exon 1. In silico prediction and validated data in the literature showed that STAT5B binding sites were found in the $\mathrm{CpG}$ island studied, while in the proximal promoter HNF4, DBP and STAT5B-binding sites were present. The analysed CpG sites sensitive to enzyme HhaI encompassed by tested primers were located proximal to STAT5Bbinding sites (Fig. 6C).

\section{Mmu-miR-155-5p may account for sexual differences in hepatic Cyp7b1 expression, while mmu-miR-142a-3p is not involved in PrIr sexually dimorphic expression}

We performed an in silico analysis using the bioinformatic tool miRSystem (Lu et al. 2012), a database which integrates seven well-known miRNA target gene prediction programs: DIANA, miRanda, miRBridge, PicTar, PITA, rna22, and TargetScan. We selected miRNAs with hits in at least three of the previously mentioned data bases. Mmu-miR155-5p and mmu-miR-142a-3p were detected as promising miRNAs to target the $C y p 7 b 1$ and Prlr genes, respectively.

The mmu-miR-155-5p which was selected as a possible modulator of $C y p 7 b 1$ expression revealed a sexually dimorphic pattern of expression $(P=0.0019$; Fig. $7 \mathrm{~A})$, with lower levels in male livers in accordance with high $C y p 7 b 1$ mRNA expression in males (Fig. 5A).

On the other hand the Prlr-directed mmu-miR142a-3p was also sexually dimorphic (Fig. 7B; $P=0.012$ ), but it did not correlate inversely but positively with Prlr expression, indicating that it is probably not involved in suppressing Prlr mRNA expression in males, but may impact on other sexually dimorphic genes as well.

No significant differences were observed in mmu-miR155-5p and mmu-miR-142-3p expression in neuroDrd2KO mice (Fig. 7C and D).

Finally, mmu-miR-155-5p was similar in females and TP females (Fig. 7E) in accordance with the lack of change of Cyp7b1 mRNA expression in these two groups (Fig. 5E), while there was a tendency to lower levels in males (as expected due to the male dominancy of this gene, $P=0.13)$. 
A
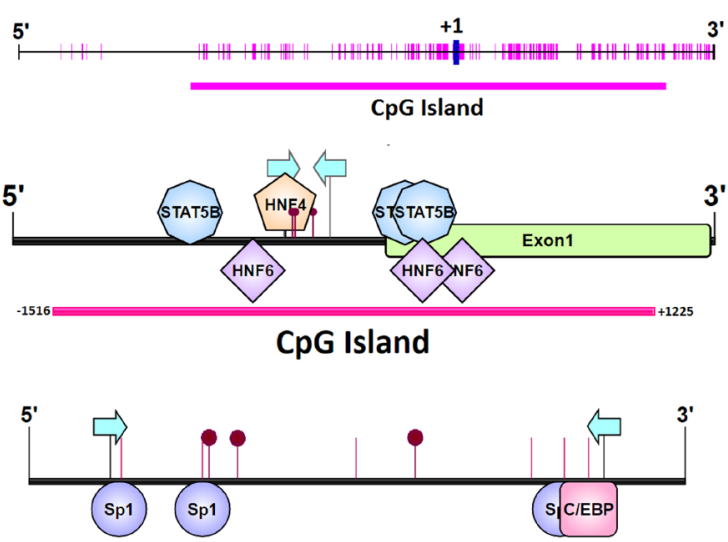

B
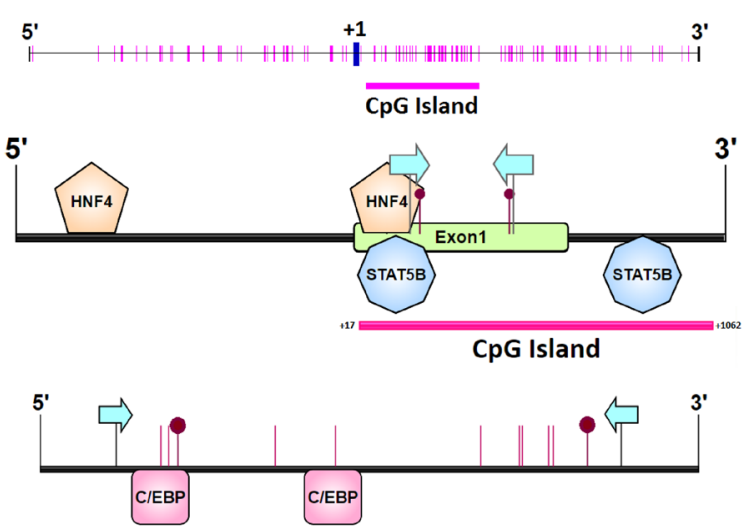

C

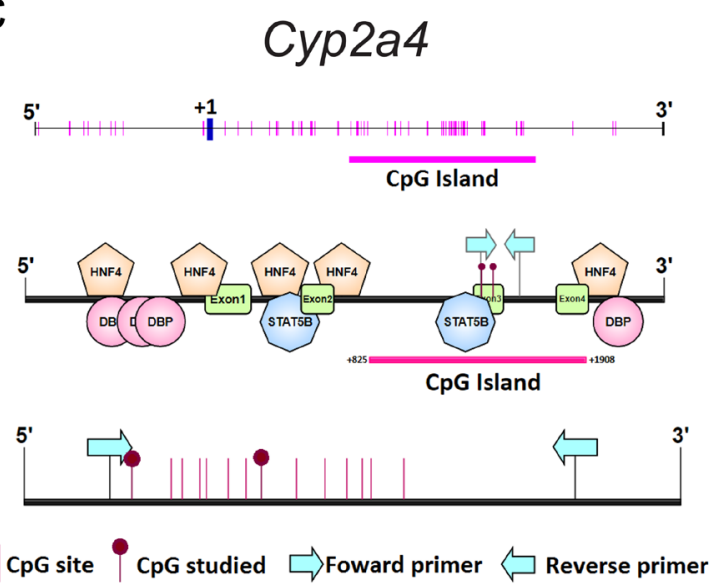

Figure 6

Schematic representation of $\mathrm{CpG}$ islands, with methylation prone CpG sites, predicted binding sites for transcription factors. (A) Hnf6, (B) Prlr, and (C) Cyp2a4. Location of binding sites for forward and reverse primers are shown by light blue arrows, CpGs are indicated by magenta vertical lines, and CpGs sensitive to restriction enzymes tested in our studies by magenta lines with a filled circle on top. TSS is indicated in a blue box $(+1)$. The schematic representations were designed using the Illustrator for Biological Sequences (Liu et al. 2015). A full colour version of this figure is available at https://doi.org/10.1530/JME-19-0205.

(c) 2020 Society for Endocrinology Published by Bioscientifica Ltd. Printed in Great Britain
Mmu-miR-142a-3p once again showed a similar pattern to Prlr gene expression in female, female TP and male livers, suggesting a lack of participation in the regulation of this gene (Fig. 7F).

\section{Discussion}

Male and female predominant liver genes represent 63 and $37 \%$, respectively, of total sex-specific liver gene expression. These sex differences depend on a highly regulated GH axis, as hypophysectomy (mostly through the loss of $\mathrm{GH}$ ) abolishes sex specificity for the majority of male- and female-predominant genes (Wauthier et al. 2010). In this context, alterations in GH secretory patterns affect liver function, and have been proposed as determinants in liver disease (Brie et al. 2019). The magnitude, as well as

\section{$\operatorname{miRNA}$}
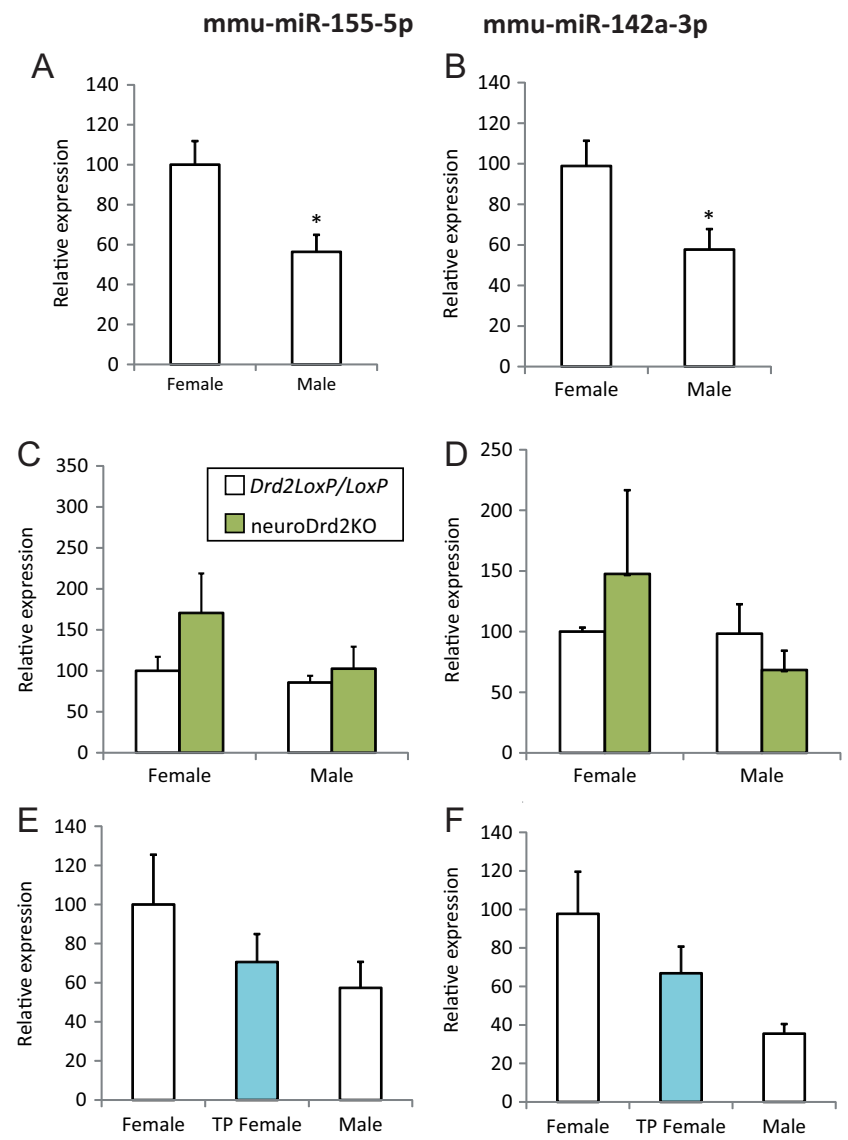

Figure 7

mmu-miR-155-59 and mmu-miR-142a-3p expression levels in (A and B) female and male mice; ( $C$ and $D$ ) female and male neuroDrd2KO and Drd2/oxp/loxp mice, and ( $E$ and $F$ ) females, neonatally androgenized females (TP female) and males. $n=12,12$ (A), 13,15 (B); 3,2,3,3 (C); 3,3,3,3 (D); 6,6,7 (E); $6,6,8$ (F). ${ }^{*} P \leq 0.05$ vs females. A full colour version of this figure is available at https://doi.org/10.1530/JME-19-0205. 
the pulsatility of GH secretion are important in setting sexual differences, and furthermore, complex epigenetic processes may intervene in establishing hormonedependent liver gene sexual dimorphism (Ling et al. 2010, Sugathan \& Waxman 2013). Chromatin structure can impact on sex-differential chromatin accessibility, sex-biased gene expression, and DNAse hypersensitive sites (DHS) (Sugathan \& Waxman 2013). Furthermore, methylation of gene promoters, or miRNA regulation of gene transcription may act differentially on specific GH-dependent liver genes, which indicates the need to unravel the complex genetic and epigenetic regulation of sexual dimorphism of GH-dependent liver genes.

In the present work we analysed the liver expression levels in correlation with the methylation status of the promoters of four female predominant genes, and one male predominant gene. Furthermore, we studied miRNAs which may target two of these genes. We first evaluated sexual dimorphism in gene expression and promoter methylation, and then studied the alterations evoked by disruption of the $\mathrm{D} 2 \mathrm{R}$ in neurons or neonatal androgenization of females. The first strategy decreases GH secretion and pulsatility in males (Noain et al. 2013), while in TP females there is a partial masculinization of the GH axis, as pituitary GH content is increased, but male pulsatility is not fully recovered (Ramirez et al. 2010).

We chose sexual dimorphic GH-dependent genes that are involved in liver metabolism and health. The prolactin receptor is a type I cytokine transmembrane receptor, which can be found in cells of mammary glands, supporting its role in lactation. But multiple homeostatic roles have been attributed to this hormone, and, in accordance, PRLRs are found in the pituitary gland, brain, heart, lung, thymus, spleen, liver, pancreas, kidney, adrenal gland, uterus, skeletal muscle, and skin (Goffin et al. 2002). Emerging roles include its participation in immune response, food intake, or islet cell proliferation (LopezVicchi \& Becu-Villalobos 2017). In the liver, protective actions have been described for the PRLR in NAFLD, HCC or inflammation (Hartwell et al. 2014, Shao et al. 2018, Zhang et al. 2018). Notably, there is a sexually dimorphic risk for HCC and NAFLD (Rogers et al. 2007) (Cheung \& Cheng 2016, Marin et al. 2016), males being more prone than females, in correlation with lower expression of liver Prlr in males (Ramirez et al. 2015). The liver PRLR has a potential clinical utility for enhancing survival of liver mass in disease, injury or surgery (Moreno-Carranza et al. 2013), or preventing liver cancer in high-risk patients (Hartwell et al. 2014). The pituitary gland, mostly dictating GH secretory patterns and prolactin secretion is involved in its sexual dimorphic expression in the liver (MorenoCarranza et al. 2013, Hartwell et al. 2014, Shao et al. 2018, Zhang et al. 2018).

CYP2A4 is a steroid $15 \alpha$-hydroxylase that catalyzes the metabolism of testosterone and estradiol in the liver. While, CYP7B1 a cytochrome P450 enzyme that hydroxylates oxysterols and steroids is paramount in hepatic bile salt synthesis, and in the inactivation of otherwise hepatotoxic oxysterols. Loss of CYP7B1 activity is associated with liver failure in children (Stiles et al. 2009)

The liver enzyme alcohol dehydrogenase metabolizes the majority of ethanol through oxidation (Simon et al. 2002). It is a female predominant GH-dependent enzyme in rodents (Potter \& Mezey 2001, Simon et al. 2002, Quintanilla et al. 2007). The defeminization of this enzyme exacerbates alcohol-induced liver damage (Ellefson et al. 2011); and, studies have determined that animals with lower ADH1 activity, or lower alcohol elimination rate, have a lower voluntary ethanol intake (Forsander \& Sinclair 1992). It is therefore relevant when considering the predisposition of toxic effects exerted by alcohol.

HNF6 is a transcription factor that binds to specific DNA sequences of numerous target gene promoters in the liver. It is involved in numerous functions such as cell proliferation or differentiation, migration, and in the liver, specifically in glucose metabolism, bile homeostasis, inflammation, being positioned as a possible target in liver fibrosis, tumorigenesis, and cholestasis (Wang \& Holterman 2012).

Our results suggest specific regulation of mRNA expression by methylation or miRNAs, indicating a complex scenario in which epigenetic regulation participates in the expression of some but not all GH-dependent sexual dimorphic liver genes.

In neuroDrd2KO mice, sexual dimorphism for all hepatic genes studied was lost, indicating that the action of the central $\mathrm{D} 2 \mathrm{R}$ is paramount in dictating sexual dimorphism of GH-dependent genes. Furthermore, in male neuroDrd2KO mice the Prlr and Cyp2a4 genes were upregulated, or feminized, while in neuroDrd2KO females the Hnf6 gene was decreased or masculinized.

Neonatal androgenization of females evoked a loss of sexual dimorphism only for the female predominant genes Hnf6 and Adh1. The masculinization of these two genes may be related to the increase in GH pituitary content induced by neonatal androgenization (Ramirez et al. 2010).

When correlating gene expression levels and methylation of the respective promoter, we found higher 
mRNA levels in females of the four female predominant genes Hnf6, Prlr, Adh1, and Cyp2a4, but lower methylation of the promoters was only detected for the Prlr and Cyp2a4 genes. Furthermore, the upregulation of these two genes in male neuroDrd2KO mice correlated with a decrease in the methylation of their promoters. Therefore, our results suggest the participation of this epigenetic process in regulating the sexual dimorphism described for Prlr and Cyp2a4.

An inverse correlation between methylation of the promoter and gene expression was also found in the downregulation of Hnf-6 in female neuroDrd2KO mice. However, in neonatally androgenized females the masculinization of Adh1 and Hnf6 mRNA levels was not related to the methylation of their promoters. Furthermore, no differences in the methylation patterns for $C y p 7 b 1$ or $A d h 1$ were found between sexes or in the neuroDrd2KO and TP models.

There are several reports which document regulation of liver genes by promoter methylation. It has been described that a postnatal gender-specific demethylation occurs exclusively in the male liver associated to the secretion of testosterone at the time of sexual maturity. The resulting methylation profile is stable and therefore can serve as an epigenetic memory (Reizel et al. 2015). For example, the male predominant $C y p 2 d 9$ promoter exhibited higher methylation status in females compared to male livers already in 2-day-old mice, and a malepreferential demethylation of this gene which correlated with the ontogeny and sex differential expression of its mRNAs in the livers of mice (Yokomori et al. 1995).

Furthermore, methylation patterns of specific liver genes have been associated to liver disease. For example, it has been documented that unique gene-expression alterations mediated by aberrant DNA methylation of selective genes may contribute to the development of HCC, and may have diagnostic value. Furthermore, using a NASH mouse model it was described that, even though 855 aberrantly methylated genes were found during the progression of the carcinogenic process, only $4 \%$ correlated inversely with gene expression (Dreval et al. 2019).

This specificity in methylation changes was also documented in human livers of an obese population. The impact of sex on DNA methylation and hepatic gene expression was studied by genome-wide DNA methylation profiling, and the methylation profile in the liver was associated with differential changes in hepatic gene expression between males and females specifically for a small proportion of genes (García-Calzón et al. 2018).

Nevertheless, other epigenetic changes may also participate, for example, distinct sex-specific activating marks at histone 3 have been described, and the femaleenriched activating K4me1 and K27ac histone marks (associated with enhancers) are found within the female predominant Cyp2a4 (Sugathan \& Waxman 2013). Furthermore, it has been described that in male livers, female-biased genes in an active chromatin state showed earlier responses to continuous GH infusion compared to those in an inactive chromatin state (Lau-Corona et al. 2017), while GH pulses increased chromatin accessibility in some but not all male genes (Connerney et al. 2017). Therefore, not only CpG methylation but other complex epigenetic events may participate in the determination sex-biased gene expression of the studied genes.

Because DNA methylation of cytosine residues can interfere with the binding of transcription factors preventing transcription we examined whether the DNA sequences in the $\mathrm{CpG}$ islands studied, and proximal to regions encompassed by selected primers, contained putative transcription factor-binding sites. In silico prediction, further narrowed down and validated by published data, showed that the analysed CpG sites in the Prlr gene contain C/EBP binding sites, and that HNF4 binding sites are found in this CpG island within exon1. C/EBP confers progesterone responsiveness leading to increased Prlr transcription in the mammary gland (Goldhar et al. 2011), and HNF4 binds to the PRLR promoter as validated by Chip analysis (Bolotin et al. 2011).

A large $\mathrm{CpG}$ island was found in the proximal promoter and exon 1 of the Hnf6 gene. Analysed CpG sites of Hnf6 encompassed by tested primers revealed binding sites for C/EBP, SP1 and HNF4. Furthermore, binding sites for HNF6 and STAT5B were predicted in the proximal promoter, and the beginning of exon1, within the $\mathrm{CpG}$ island. The SP1 proteins are ubiquitously expressed, and interact with general transcription factors, while C/EBP regulates the expression of some liver genes, in particular HNF6-dependent transcription (Yoshida et al. 2006). Furthermore, it has been demonstrated that GH stimulates transcription of the Hnf6 gene by a mechanism involving binding of STAT5 and HNF4 to its promoter, and that HNF6 is not only a transcription factor but a target to the regulatory network of liver transcription factors many of which are regulated by GH (Lahuna et al. 2000).

Finally many binding sites for transcription factors (HNF4, albumin D-binding protein (DBP) and STAT5B) have been described in the proximal promoter of the Cyp2a4 gene (Mueller et al. 1990, Miura \& Tanaka 1993, Zhang et al. 2012). Within the CpG island located in exon 1 a STAT5B-binding sites were described (Zhang et al. 2012), It was shown that STAT5B nuclear localization 
correlates with the repression of Cyp2a4 in males (Sueyoshi et al. 1999) and therefore could contribute to the sex specificity of this gene. Similarly HNF4 regulates Cyp2a4 in male livers (Wiwi et al. 2004). On the other hand, DBP is highly concentrated in liver compared to other tissues, and during chemically induced liver regeneration, its expression is rapidly downregulated, suggesting that DBP may be involved in the proliferation control of hepatocytes. Furthermore DBP can regulate Cyp2a4 expression levels in the liver (Lavery et al. 1999).

Methylation of transcription binding sites generally prevents the transcriptional machinery from accessing start sites on a gene, therefore it is conceivable that higher methylation in males of HNF4 and STAT5B-binding sites in the Cyp2a4 promoter, or HNF4 in the Prlr promoter may maintain a low transcription rate, while the decrease in methylation in neuroDrd2KO males may favor transcription of these two genes.

Mmu-miR-155-5p, a miRNA predicted to target Cyp7b1 expression, was lower in males and could account for higher $C y p 7 b 1$ mRNA levels in this sex. It was not modified by neuron deletion of D2Rs or neonatal androgenization of females. On the other hand, even when mmu-miR-142a-3p was predicted to target the Prlr gene, it did not correlate inversely with its expression, indicating that it is not involved in establishing the sexual differences for this gene in the liver, and that bioinformatic tools are not sufficient to determine miRNA regulation of genes. The analysis of two miRNA is indicative of gene control through this mechanism, and other sex-biased GH-dependent miRNAs in the liver may also modify hepatic sexual dimorphism (Hao \& Waxman 2018). For example, the male-biased miR-1948 and the female-biased miR-802 are both regulated by sex-specific pituitary GH secretory patterns, acquire sex specificity at puberty, and are dependent on the GH-activated transcription factor STAT5 for their sexspecific expression (Hao \& Waxman 2018).

Understanding the specificity of epigenetic regulation of gene expression is an increasing concern. Our results show that liver Prlr expression may be regulated by methylation of its promoter. This receptor stimulates normal liver growth and participates in liver regeneration (Moreno-Carranza et al. 2013). Downregulation of liver Prlr may be involved in hepatic steatosis and NAFLD occurrence in experimental models and obese patients (Shao et al. 2018, Zhang et al. 2018), and the PRLR may protect from HCC by promoting innate immune signaling, and preventing the activation of the HCC-associated gene c-Myc (Hartwell et al. 2014). Targeting DNA methylation for cancer therapy has long been proposed (Issa 2007) and inhibitors of DNA methyltransferases have been approved for clinical use for what is termed epigenetic therapy. It is therefore paramount to elucidate genes whose expression may specifically be modified by hypomethylation therapy.

Furthermore, we show that, in our experimental models mmu-miR-155-5p which targets Cyp7b1 expression may participate in the GH-dependent sexual differences observed for this gene, an important modifier of oxysterol metabolism, associated to pediatric liver failure (Stiles et al. 2009). To this regard, miRNA-based therapies in cancer (Garzon et al. 2010), neurological pathologies (Ruberti et al. 2012), and pathological heart hypertrophy and cardiac failure (Lv et al. 2015) are being developed. In the liver, miRNAs or miRNA inhibitors have been used as liver cancer therapeutics. New technologies are being developed in order to optimize the delivery of miRNAs to the liver without having any toxicity or side effects in other major organs (Drakaki et al. 2013). In this context, the validation of miRNA action on different tissues and biological circuits is a growing area or research.

\section{Declaration of interest}

The authors declare that there is no conflict of interest that could be perceived as prejudicing the impartiality of the research reported.

\section{Funding}

This work was supported by grants from Agencia Nacional de Promoción Científica y Tecnológica, Argentina; PICT 1343-2015; PICT 526-2016, Fundación Rene Barón 2018, Fundación Williams 2018, Consejo Nacional de Investigaciones Científicas y Técnicas PIP 561-2014.

\section{References}

Bello EP, Mateo Y, Gelman DM, Noain D, Shin JH, Low MJ, Alvarez VA, Lovinger DM \& Rubinstein M 2011 Cocaine supersensitivity and enhanced motivation for reward in mice lacking dopamine D2 autoreceptors. Nature Neuroscience 14 1033-1038. (https://doi. org/10.1038/nn.2862)

Bolotin E, Chellappa K, Hwang-Verslues W, Schnabl JM, Yang C \& Sladek FM 2011 Nuclear receptor HNF4alpha binding sequences are widespread in Alu repeats. BMC Genomics 12 560. (https://doi. org/10.1186/1471-2164-12-560)

Brie B, Ramirez MC, De Winne C, Lopez Vicchi F, Villarruel L, Sorianello E, Catalano P, Ornstein AM \& Becu-Villalobos D 2019 Brain control of sexually dimorphic liver function and disease: the endocrine connection. Cellular and Molecular Neurobiology 39 169-180. (https://doi.org/10.1007/s10571-019-00652-0)

Buzzetti E, Parikh PM, Gerussi A \& Tsochatzis E 2017 Gender differences in liver disease and the drug-dose gender gap. Pharmacological Research 120 97-108. (https://doi.org/10.1016/j.phrs.2017.03.014)

Cheung OK \& Cheng AS 2016 Gender differences in adipocyte metabolism and liver cancer progression. Frontiers in Genetics 7168. (https://doi.org/10.3389/fgene.2016.00168)

Clodfelter KH, Miles GD, Wauthier V, Holloway MG, Zhang X, Hodor P, Ray WJ \& Waxman DJ 2007 Role of STAT5a in regulation of sexspecific gene expression in female but not male mouse liver revealed 
by microarray analysis. Physiological Genomics 31 63-74. (https://doi org/10.1152/physiolgenomics.00055.2007)

Connerney J, Lau-Corona D, Rampersaud A \& Waxman DJ 2017 Activation of male liver chromatin accessibility and STAT5-dependent gene transcription by plasma growth hormone pulses. Endocrinology 158 1386-1405. (https://doi.org/10.1210/en.2017-00060)

Drakaki A, Hatziapostolou M \& Iliopoulos D 2013 Therapeutically targeting microRNAs in liver cancer. Current Pharmaceutical Design 19 1180-1191. (https://doi.org/10.2174/138161213804805658)

Dreval K, Tryndyak V, de Conti A, Beland FA \& Pogribny IP 2019 Gene expression and DNA methylation alterations during non-alcoholic steatohepatitis-associated liver carcinogenesis. Frontiers in Genetics 10 486. (https://doi.org/10.3389/fgene.2019.00486)

Durazzo M, Belci P, Collo A, Prandi V, Pistone E, Martorana M, Gambino R \& Bo S 2014 Gender specific medicine in liver diseases: a point of view. World Journal of Gastroenterology 20 2127-2135. (https://doi.org/10.3748/wjg.v20.i9.2127)

Ellefson WM, Lakner AM, Hamilton A, McKillop IH, Bonkovsky HL, Steuerwald NM, Huet YM \& Schrum LW 2011 Neonatal androgenization exacerbates alcohol-induced liver injury in adult rats, an effect abrogated by estrogen. PLOS ONE 6 e29463. (https:// doi.org/10.1371/journal.pone.0029463)

Forsander OA \& Sinclair JD 1992 Alcohol elimination and the regulation of alcohol consumption in AA and ANA rats. Alcohol and Alcoholism 27 411-416. (https://doi.org/10.1093/oxfordjournals.alcalc.a045266)

García-Calzón S, Perfilyev A, de Mello VD, Pihlajamäki J \& Ling C 2018 Sex differences in the methylome and transcriptome of the human liver and circulating HDL-cholesterol levels. Journal of Clinical Endocrinology and Metabolism 103 4395-4408. (https://doi. org/10.1210/jc.2018-00423)

Garcia-Carpizo V, Ruiz-Llorente L, Fraga M \& Aranda A 2011 The growing role of gene methylation on endocrine function. Journal of Molecular Endocrinology 47 R75-R89. (https://doi.org/10.1530/JME-11-0059)

Garzon R, Marcucci G \& Croce CM 2010 Targeting microRNAs in cancer: rationale, strategies and challenges. Nature Reviews: Drug Discovery 9 775-789. (https://doi.org/10.1038/nrd3179)

Goffin V, Binart N, Touraine P \& Kelly PA 2002 Prolactin: the new biology of an old hormone. Annual Review of Physiology 64 47-67. (https://doi.org/10.1146/annurev.physiol.64.081501.131049)

Goldhar AS, Duan R, Ginsburg E \& Vonderhaar BK 2011 Progesterone induces expression of the prolactin receptor gene through cooperative action of Sp1 and C/EBP. Molecular and Cellular Endocrinology 335 148157. (https://doi.org/10.1016/j.mce.2011.01.004)

Guy J \& Peters MG 2013 Liver disease in women: the influence of gender on epidemiology, natural history, and patient outcomes. Gastroenterology and Hepatology 9 633-639.

Hao P \& Waxman DJ 2018 Functional roles of sex-biased, growth hormone-regulated microRNAs miR-1948 and miR-802 in young adult mouse liver. Endocrinology 159 1377-1392. (https://doi. org/10.1210/en.2017-03109)

Hartwell HJ, Petrosky KY, Fox JG, Horseman ND \& Rogers AB 2014 Prolactin prevents hepatocellular carcinoma by restricting innate immune activation of c-Myc in mice. PNAS 111 11455-11460. (https://doi.org/10.1073/pnas.1404267111)

Holloway MG, Laz EV \& Waxman DJ 2006 Codependence of Growth Hormone-Responsive, Sexually Dimorphic Hepatic Gene Expression on Signal Transducer and Activator of Transcription $5 b$ and Hepatic Nuclear Factor 4 $\alpha$. Molecular Endocrinology 20 647-660. (https://doi. org/10.1210/me.2005-0328)

Issa JP 2007 DNA methylation as a therapeutic target in cancer. Clinical Cancer Research 13 1634-1637. (https://doi.org/10.1158/1078-0432. CCR-06-2076)

Jansson JO \& Frohman LA 1987 Differential effects of neonatal and adult androgen exposure on the growth hormone secretory pattern in male rats. Endocrinology 120 1551-1557. (https://doi.org/10.1210/ endo-120-4-1551)
Lahuna O, Rastegar M, Maiter D, Thissen JP, Lemaigre FP \& Rousseau GG 2000 Involvement of STAT5 (signal transducer and activator of transcription 5) and HNF-4 (hepatocyte nuclear factor 4) in the transcriptional control of the hnf6 gene by growth hormone. Molecular Endocrinology 14 285-294. (https://doi.org/10.1210/mend.14.2.0423)

Lau-Corona D, Suvorov A \& Waxman DJ 2017 Feminization of male mouse liver by persistent growth hormone stimulation: activation of sex-biased transcriptional networks and dynamic changes in chromatin states. Molecular and Cellular Biology 37 00301-00317. (https://doi.org/10.1128/MCB.00301-17)

Lavery DJ, Lopez-Molina L, Margueron R, Fleury-Olela F, Conquet F, Schibler U \& Bonfils C 1999 Circadian expression of the steroid 15 alpha-hydroxylase (Сyp2a4) and coumarin 7-hydroxylase (Сyp2a5) genes in mouse liver is regulated by the PAR leucine zipper transcription factor DBP. Molecular and Cellular Biology 19 6488-6499. (https://doi.org/10.1128/mcb.19.10.6488)

Lenz KM, Nugent BM \& McCarthy MM 2012 Sexual differentiation of the rodent brain: dogma and beyond. Frontiers in Neuroscience 626. (https://doi.org/10.3389/fnins.2012.00026)

Liao D, Porsch-Hallstrom I, Gustafsson JA \& Blanck A 1993 Sex differences at the initiation stage of rat liver carcinogenesis-influence of growth hormone. Carcinogenesis 14 2045-2049. (https://doi. org/10.1093/carcin/14.10.2045)

Ling G, Sugathan A, Mazor T, Fraenkel E \& Waxman DJ 2010 Unbiased, genome-wide in vivo mapping of transcriptional regulatory elements reveals sex differences in chromatin structure associated with sexspecific liver gene expression. Molecular and Cellular Biology 30 5531-5544. (https://doi.org/10.1128/MCB.00601-10)

Liu W, Xie Y, Ma J, Luo X, Nie P, Zuo Z, Lahrmann U, Zhao Q, Zheng Y, Zhao Y, et al. 2015 IBS: an illustrator for the presentation and visualization of biological sequences. Bioinformatics 31 3359-3361. (https://doi.org/10.1093/bioinformatics/btv362)

Livne I, Silverman AJ \& Gibson MJ 1992 Reversal of reproductive deficiency in the hpg male mouse by neonatal androgenization. Biology of Reproduction 47 561-567. (https://doi.org/10.1095/biolreprod47.4.561)

Lopez-Vicchi F \& Becu-Villalobos D 2017 Prolactin: the bright and the dark side. Endocrinology 158 1556-1559. (https://doi.org/10.1210/ en.2017-00184)

Lu TP, Lee CY, Tsai MH, Chiu YC, Hsiao CK, Lai LC \& Chuang EY 2012 miRSystem: an integrated system for characterizing enriched functions and pathways of microRNA targets. PLOS ONE 7 e42390. (https://doi.org/10.1371/journal.pone.0042390)

Lv D, Liu J, Zhao C, Sun Q, Zhou Q, Xu J \& Xiao J 2015 Targeting microRNAs in pathological hypertrophy and cardiac failure. Mini Reviews in Medicinal Chemistry 15 475-478. (https://doi.org/10.2174/ 1389557515666150324124751)

Marin V, Rosso N, Dal Ben M, Raseni A, Boschelle M, Degrassi C, Nemeckova I, Nachtigal P, Avellini C, Tiribelli C, et al. 2016 An animal model for the juvenile non-alcoholic fatty liver disease and non-alcoholic steatohepatitis. PLoS ONE 11 e0158817. (https://doi. org/10.1371/journal.pone.0158817)

Messeguer X, Escudero R, Farre D, Nunez O, Martinez J \& Alba MM 2002 PROMO: detection of known transcription regulatory elements using species-tailored searches. Bioinformatics 18 333-334. (https:// doi.org/10.1093/bioinformatics/18.2.333)

Miura N \& Tanaka K 1993 Analysis of the rat hepatocyte nuclear factor (HNF) 1 gene promoter: synergistic activation by HNF4 and HNF1 proteins. Nucleic Acids Research 21 3731-3736. (https://doi. org/10.1093/nar/21.16.3731)

Moreno-Carranza B, Goya-Arce M, Vega C, Adan N, Triebel J, LopezBarrera F, Quintanar-Stephano A, Binart N, Martínez de la Escalera G \& Clapp C 2013 Prolactin promotes normal liver growth, survival, and regeneration in rodents: effects on hepatic IL-6, suppressor of cytokine signaling-3, and angiogenesis. American Journal of Physiology: Regulatory, Integrative and Comparative Physiology 305 R720-R726. (https://doi.org/10.1152/ajpregu.00282.2013) 
Mueller CR, Maire P \& Schibler U 1990 DBP, a liver-enriched transcriptional activator, is expressed late in ontogeny and its tissue specificity is determined posttranscriptionally. Cell $61279-291$. (https://doi.org/10.1016/0092-8674(90)90808-r)

Negri-Cesi P, Colciago A, Pravettoni A, Casati L, Conti L \& Celotti F 2008 Sexual differentiation of the rodent hypothalamus: hormonal and environmental influences. Journal of Steroid Biochemistry and Molecular Biology 109 294-299. (https://doi.org/10.1016/j. jsbmb.2008.03.003)

Noain D, Perez-Millan MI, Bello EP, Luque GM, Casas Cordero R, Gelman DM, Peper M, Tornadu IG, Low MJ, Becu-Villalobos D, et al. 2013 Central dopamine D2 receptors regulate growth-hormonedependent body growth and pheromone signaling to conspecific males. Journal of Neuroscience 33 5834-5842. (https://doi. org/10.1523/JNEUROSCI.5673-12.2013)

Nugent BM \& McCarthy MM 2011 Epigenetic underpinnings of developmental sex differences in the brain. Neuroendocrinology 93 150-158. (https://doi.org/10.1159/000325264)

Potter JJ \& Mezey E 2001 Effect of STAT5b on rat liver alcohol dehydrogenase. Archives of Biochemistry and Biophysics 391 41-48. (https://doi.org/10.1006/abbi.2001.2393)

Poynard T, Bedossa P \& Opolon P 1997 Natural history of liver fibrosis progression in patients with chronic hepatitis C. The OBSVIRC, METAVIR, CLINIVIR, and DOSVIRC groups. Lancet 349 825-832. (https://doi.org/10.1016/s0140-6736(96)07642-8)

Quintanilla ME, Tampier L, Sapag A, Gerdtzen Z \& Israel Y 2007 Sex differences, alcohol dehydrogenase, acetaldehyde burst, and aversion to ethanol in the rat: a systems perspective. American Journal of Physiology: Endocrinology and Metabolism 293 E531-E537. (https://doi. org/10.1152/ajpendo.00187.2007)

Ramirez MC, Luque GM, Ornstein AM \& Becu-Villalobos D 2010 Differential neonatal testosterone imprinting of GH-dependent liver proteins and genes in female mice. Journal of Endocrinology 207 301-308. (https://doi.org/10.1677/JOE-10-0276)

Ramirez MC, Bourguignon NS, Bonaventura MM, Lux-Lantos V, Libertun C \& Becu-Villalobos D 2012 Neonatal xenoestrogen exposure alters growth hormone-dependent liver proteins and genes in adult female rats. Toxicology Letters 213 325-331. (https://doi. org/10.1016/j.toxlet.2012.07.015)

Ramirez MC, Ornstein AM, Luque GM, Perez-Millan MI, GarciaTornadu I, Rubinstein M \& Becu-Villalobos D 2015 Pituitary and brain dopamine D2 receptors regulate liver gene sexual dimorphism. Endocrinology 156 1040-1051. (https://doi.org/10.1210/en.2014-1714)

Reizel Y, Spiro A, Sabag O, Skversky Y, Hecht M, Keshet I, Berman BP \& Cedar H 2015 Gender-specific postnatal demethylation and establishment of epigenetic memory. Genes and Development 29 923-933. (https://doi.org/10.1101/gad.259309.115)

Rogers AB, Theve EJ, Feng Y, Fry RC, Taghizadeh K, Clapp KM, Boussahmain C, Cormier KS \& Fox JG 2007 Hepatocellular carcinoma associated with liver-gender disruption in male mice. Cancer Research 67 11536-11546. (https://doi.org/10.1158/00085472.CAN-07-1479)

Ruberti F, Barbato C \& Cogoni C 2012 Targeting microRNAs in neurons: tools and perspectives. Experimental Neurology 235 419-426. (https:// doi.org/10.1016/j.expneurol.2011.10.031)

Shao S, Yao Z, Lu J, Song Y, He Z, Yu C, Zhou X, Zhao L, Zhao J \& Gao L 2018 Ablation of prolactin receptor increases hepatic triglyceride accumulation. Biochemical and Biophysical Research Communications 498 693-699. (https://doi.org/10.1016/j.bbrc.2018.03.048)

Simon FR, Fortune J, Iwahashi M \& Sutherland E 2002 Sexual dimorphic expression of $\mathrm{ADH}$ in rat liver: importance of the hypothalamicpituitary-liver axis. American Journal of Physiology: Gastrointestinal and
Liver Physiology 283 G646-G655. (https://doi.org/10.1152/ ajpgi.00438.2001)

Stiles AR, McDonald JG, Bauman DR \& Russell DW 2009 CYP7B1: one cytochrome P450, two human genetic diseases, and multiple physiological functions. Journal of Biological Chemistry $\mathbf{2 8 4}$ 28485-28489. (https://doi.org/10.1074/jbc.R109.042168)

Sueyoshi T, Yokomori N, Korach KS \& Negishi M 1999 Developmental action of estrogen receptor-alpha feminizes the growth hormoneStat5b pathway and expression of Cyp2a4 and Cyp2d9 genes in mouse liver. Molecular Pharmacology 56 473-477. (https://doi. org $/ 10.1124 / \mathrm{mol} .56 .3 .473)$

Sugathan A \& Waxman DJ 2013 Genome-wide analysis of chromatin states reveals distinct mechanisms of sex-dependent gene regulation in male and female mouse liver. Molecular and Cellular Biology $\mathbf{3 3}$ 3594-3610. (https://doi.org/10.1128/MCB.00280-13)

Tracy TS, Venkataramanan R, Glover DD, Caritis SN \& National Institute for Child Health and Human Development Network of MaternalFetal-Medicine Units 2005 Temporal changes in drug metabolism (CYP1A2, CYP2D6 and CYP3A Activity) during pregnancy. American Journal of Obstetrics and Gynecology 192 633-639. (https://doi. org/10.1016/j.ajog.2004.08.030)

Wang K \& Holterman AX 2012 Pathophysiologic role of hepatocyte nuclear factor 6. Cellular Signalling 24 9-16. (https://doi. org/10.1016/j.cellsig.2011.08.009)

Wauthier V, Sugathan A, Meyer RD, Dombkowski AA \& Waxman DJ 2010 Intrinsic sex differences in the early growth hormone responsiveness of sex-specific genes in mouse liver. Molecular Endocrinology 24 667-678. (https://doi.org/10.1210/me.2009-0454)

Waxman DJ \& Holloway MG 2009 Sex differences in the expression of hepatic drug metabolizing enzymes. Molecular Pharmacology $\mathbf{7 6}$ 215-228. (https://doi.org/10.1124/mol.109.056705)

Wiwi CA, Gupte M \& Waxman DJ 2004 Sexually dimorphic P450 gene expression in liver-specific hepatocyte nuclear factor 4alpha-deficient mice. Molecular Endocrinology 18 1975-1987. (https://doi. org/10.1210/me.2004-0129)

Wong JH, Dukes J, Levy RE, Sos B, Mason SE, Fong TS \& Weiss EJ 2008 Sex differences in thrombosis in mice are mediated by sex-specific growth hormone secretion patterns. Journal of Clinical Investigation 118 2969-2978. (https://doi.org/10.1172/JCI34957)

Yokomori N, Kobayashi R, Moore R, Sueyoshi T \& Negishi M 1995 A DNA methylation site in the male-specific P450 (Cyp 2d-9) promoter and binding of the heteromeric transcription factor GABP. Molecular and Cellular Biology 15 5355-5362. (https://doi.org/10.1128/ mcb.15.10.5355)

Yoshida Y, Hughes DE, Rausa III FM, Kim IM, Tan Y, Darlington GJ \& Costa RH 2006 C/EBPalpha and HNF6 protein complex formation stimulates HNF6-dependent transcription by CBP coactivator recruitment in HepG2 cells. Hepatology 43 276-286. (https://doi. org/10.1002/hep.21044)

Zhang Y, Klein K, Sugathan A, Nassery N, Dombkowski A, Zanger UM \& Waxman DJ 2011 Transcriptional profiling of human liver identifies sex-biased genes associated with polygenic dyslipidemia and coronary artery disease. PLoS ONE 6 e23506. (https://doi. org/10.1371/journal.pone.0023506)

Zhang Y, Laz EV \& Waxman DJ 2012 Dynamic, sex-differential STAT5 and BCL6 binding to sex-biased, growth hormone-regulated genes in adult mouse liver. Molecular and Cellular Biology 32 880-896. (https:// doi.org/10.1128/MCB.06312-11)

Zhang P, Ge Z, Wang H, Feng W, Sun X, Chu X, Jiang C, Wang Y, Zhu D \& Bi Y 2018 Prolactin improves hepatic steatosis via CD36 pathway. Journal of Hepatology 68 1247-1255. (https://doi.org/10.1016/j. jhep.2018.01.035)

Received in final form 2 January 2020

Accepted 21 January 2020

Accepted Manuscript published online 21 January 2020 https://jme.bioscientifica.com https://doi.org/10.1530/JME-19-0205 (c) 2020 Society for Endocrinology Published by Bioscientifica Ltd. Printed in Great Britain 